\title{
CONTROLLING INTERMEDIATE TEMPERATURE FATIGUE CRACK GROWTH IN NICKEL BASE SUPERALLOYS BY MICROSTRUCTURAL VARIATIONS
}

S. Floreen and R. H. Kane Inco Research \& Development Center Sterling Forest, Suffern, NY 10901

Increasing the grain size of superalloys markedly reduced the $650^{\circ} \mathrm{C}$ fatigue crack growth rates in air and in helium. Grain boundary microstructure changes and overaging also were beneficial in air, but not in helium. Structures optimized by testing in air may not be effective when some species other than oxygen dominates the environment.

\section{INTRODUCTION}

The role of microstructure in elevated temperature fatigue crack growth is not clear. At $1 \mathrm{~Hz}$ increasing the grain size was found to reduce crack growth rates(1), but overaging heat treatments produced no significant changes $(1,2)$. At lower frequencies however, overaging has been found to be beneficial $(2,3-6)$. Overaging also is beneficial in creep loading. Homogenizing slip within the grains, and/or changing the grain boundary microstructure have been cited as the reasons for the improvement in properties(7).

In the present study the fatigue crack growth behavior of a number of Ni-base superalloys was examined. The hot working and heat treating histories were varied to produce changes in the grain size, grain shape and carbide, gamma prime, and inclusion particle morphologies. Tests were run in air and also in high purity Helium so that the effects of the air environment could be evaluated.

\section{EXPERIMENTAL PROCEDURE}

Table 1 summarizes the alloys examined and the processing history uscd to vary the microstructures. The variations in structure with each alloy were as follows: 
Table 1. Materials Processing History.

\begin{tabular}{|c|c|c|}
\hline Alloy & Code & Processing History \\
\hline \multirow[t]{3}{*}{ ASTROLOY } & A & $\begin{array}{l}1095^{\circ} \mathrm{C} / 1 \mathrm{~h} / \mathrm{AC}+650^{\circ} \mathrm{C} / 24 \mathrm{~h} / \mathrm{AC}+ \\
760^{\circ} \mathrm{C} / 8 \mathrm{~h} / \mathrm{AC}\end{array}$ \\
\hline & B & $\begin{array}{l}1165^{\circ} \mathrm{C} / 1 \mathrm{~h} / \mathrm{AC}+650^{\circ} \mathrm{C} / 24 \mathrm{~h} / \mathrm{AC}+ \\
760^{\circ} \mathrm{C} / 8 \mathrm{~h} / \mathrm{AC}\end{array}$ \\
\hline & C & $\begin{array}{l}1165^{\circ} \mathrm{C} / 1 \mathrm{~h} / \mathrm{FC} \text { to } 1065^{\circ} \mathrm{C} / \mathrm{AC}+ \\
650^{\circ} \mathrm{C} / 24 \mathrm{~h} / \mathrm{AC}+760^{\circ} \mathrm{C} / 8 \mathrm{~h} / \mathrm{AC}\end{array}$ \\
\hline \multirow[t]{2}{*}{ NIMONIC* alloy 115} & $\mathrm{D}$ & $1190^{\circ} \mathrm{C} / 2 \mathrm{~h} / \mathrm{FC}$ to $1000^{\circ} \mathrm{C} / \mathrm{AC}$ \\
\hline & $\mathbf{E}$ & $1190^{\circ} \mathrm{C} / 2 \mathrm{~h} / \mathrm{AC}+1075^{\circ} \mathrm{C} / 6 \mathrm{~h} / \mathrm{AC}$ \\
\hline \multirow[t]{2}{*}{ INCONEL* alloy $\mathrm{X}-750$} & $\mathbf{F}$ & $\begin{array}{l}1095^{\circ} \mathrm{C} / 2 \mathrm{~h} / \mathrm{WQ}+885^{\circ} \mathrm{C} / 24 \mathrm{~h} / \mathrm{AC}+ \\
705^{\circ} \mathrm{C} / 20 \mathrm{~h} / \mathrm{AC}\end{array}$ \\
\hline & G & $1095^{\circ} \mathrm{C} / 2 \mathrm{~h} / \mathrm{WQ}+705^{\circ} \mathrm{C} / 20 \mathrm{~h} / \mathrm{AC}$ \\
\hline \multirow[t]{3}{*}{ WASPALOY -1} & $\mathrm{H}$ & $\begin{array}{l}\text { As-forged }+845^{\circ} \mathrm{C} / 24 \mathrm{~h} / \mathrm{AC}+ \\
760^{\circ} \mathrm{C} / 16 \mathrm{~h} / \mathrm{AC}\end{array}$ \\
\hline & $\mathrm{J}$ & $\begin{array}{l}1095^{\circ} \mathrm{C} / 1 \mathrm{~h} / \mathrm{WQ}+845^{\circ} \mathrm{C} / 24 \mathrm{~h} / \mathrm{AC}+ \\
760^{\circ} \mathrm{C} / 16 \mathrm{~h} / \mathrm{AC}\end{array}$ \\
\hline & $\mathrm{K}$ & $\begin{array}{l}1175^{\circ} \mathrm{C} / 4 \mathrm{~h} / \mathrm{WQ}+845^{\circ} \mathrm{C} / 24 \mathrm{~h} / \mathrm{AC}+ \\
760^{\circ} \mathrm{C} / 16 \mathrm{~h} / \mathrm{AC}\end{array}$ \\
\hline \multirow[t]{2}{*}{ WASPALOY -2} & I & $\begin{array}{l}1095^{\circ} \mathrm{C} / \text { Hot Roll+845 }{ }^{\circ} \mathrm{C} / 24 \mathrm{~h} / \mathrm{ACt} \\
760^{\circ} \mathrm{C} / 16 \mathrm{~h} / \mathrm{AC}-\text { Longitudinal } \\
\text { Orientation }\end{array}$ \\
\hline & $\mathrm{M}$ & $\begin{array}{l}1095^{\circ} \mathrm{C} / \text { Hot } \mathrm{Rol} 1+845^{\circ} \mathrm{C} / 24 \mathrm{~h} / \mathrm{AC}+ \\
760^{\circ} \mathrm{C} / 16 \mathrm{~h} / \mathrm{AC}-\text { Transverse } \\
\text { Orientation }\end{array}$ \\
\hline \multirow[t]{2}{*}{ WASPALOY -3} & $\overline{0}$ & $\begin{array}{l}1035^{\circ} \mathrm{C} / \mathrm{Hot} \text { Roll }+845^{\circ} \mathrm{C} / 24 \mathrm{~h} / \mathrm{AC}+ \\
760^{\circ} \mathrm{C} / 16 \mathrm{~h} / \mathrm{AC}-L o n g i t u d i n a l \\
\text { Orientation }\end{array}$ \\
\hline & $P$ & $\begin{array}{l}1035^{\circ} \mathrm{C} / \mathrm{Hot} \text { Roll }+845^{\circ} \mathrm{C} / 24 \mathrm{~h} / \mathrm{AC}+ \\
760^{\circ} \mathrm{C} / 16 \mathrm{~h} / \mathrm{AC}-\text { Transverse } \\
\text { Orientation }\end{array}$ \\
\hline
\end{tabular}

Astroloy - The solution heat treatment was varied to change the grain size, codes $A$ and $B$, and a furnace cooling after solution annealing, Code $C$, was used to introduce serrated grain boundaries( 8$)$.

NIMONIC* Alloy 115 - Furnace cooling after solution annealing was employed to produce a blocky $\mathrm{M}_{23} \mathrm{C}_{6}$ grain boundary carbide (Code D). Air cooling after solution annealing followed by a $1075^{\circ} \mathrm{C}$ heat treatment (Code $\mathrm{E}$ ) was employed to produce a semi-continuous $\mathrm{M}_{23} \mathrm{C}_{6}$ grain boundary carbide(9). 
INCONEL* alloy $\mathrm{X}-750$ - An intermediate $885^{\circ} \mathrm{C}$ heat treatment before aging, code $F$, was used to produce extensive $\mathrm{M}_{23} \mathrm{C}_{6}$ grain boundary carbide and a grain boundary zone denuded of $\gamma^{\prime}(10)$. Omitting this treatment, Code F, produced a much tiner carbide and less denuded zone.

Waspaloy-1 - Stock was given different solution heat treatments to produce equiaxed grains of various sizes, Codes $\mathrm{H}, \mathrm{J}$ and $\mathrm{K}$.

Waspaloy-2 - Stock was hot rolled at $1095^{\circ} \mathrm{C}$ and aged to produce a duplex microstructure of coarse and very fine grains strung out parallel to the rolling direction. Samples were cut in the longitudinal (Code $L$ ) and transverse (Code M) directions.

Waspaloy-3 - Stock was hot rolled at $1035^{\circ} \mathrm{C}$ and aged to produce equiaxed grains with inclusion stringers parallel to the rolling direction. Samples were again cut in longitudinal (Code 0 ) and transverse (Code P) orientations.

Compact tension fracture toughness samples were machined from the stock materials. Test specimens were $30.5 \mathrm{~mm} \times$ $29.3 \mathrm{~mm} \times 9.2 \mathrm{~mm}$ thick following the dimensions used in earlier studies(12). After machining the samples were fatigue precracked at room temperature at low stress intensities so that more than 50,000 cycles were used to grow the starting cracks.

The test facility has been described in detail in an earlier paper(11). Specimens were brought to temperature and exposed to the environment, either air or $99.995 \%$ pure helium, for about one hour before loading. All tests were at $650^{\circ} \mathrm{C}$ under load control using sine wave loading form. Tests were run at an $R$ ratio of 0.1 and a frequency of 0.1 $\mathrm{Hz}$. After testing the fracture surfaces were examined optically and in many cases by scanning electron microscopy.

\section{RESULTS AND DISCUSSION}

Figure 1 shows the crack growth rates da/dN plotted against the stress intensity range $\Delta \mathrm{K}$. To facilitate comparison of the results the crack growth rates at a $\Delta \mathrm{K}$ value of $35 \mathrm{MPa} / \mathrm{m}$ are summarized in Table 2 . To broaden the comparison the results from an earlier study(2) of crack growth in INCONEL alloy 718 are included in Table 2. These tests are run under identical test conditions to those used 
Examination of Table 2 shows that some very significant changes in crack growth rates were achieved in the Astroloy and Waspaloy specimens in which the grain sizes and shapes were varied. Figure 3 shows a plot of the crack growth rates at ${ }_{\Delta} \mathrm{K}=35 \mathrm{MPa}, \mathrm{m}$ versus the grain size. To a first approximation the data can be represented by a straight line for each environment with slope of -1 on a $l o g-10 g$ plot. At all grain sizes the crack growth rates in air were about 2.5 times faster than in He.

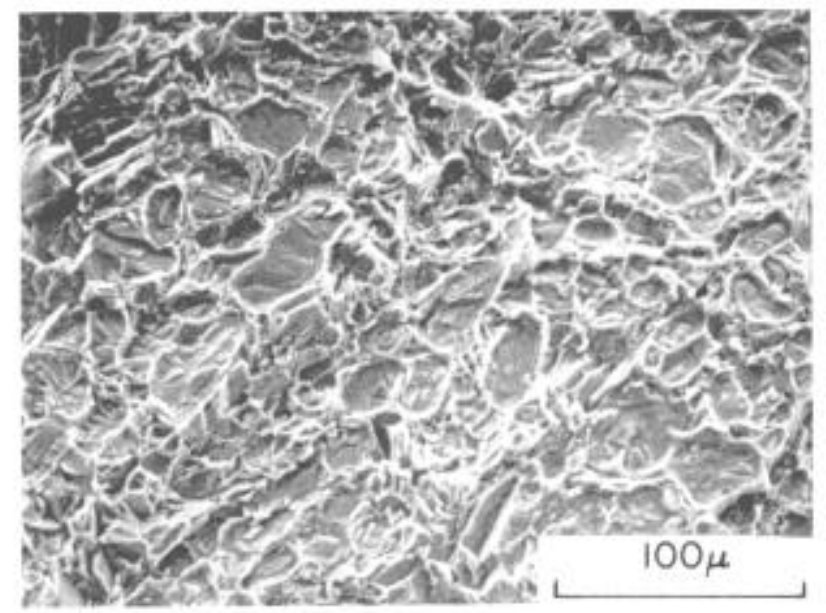

PIGURE 2: Scanning electron micrograph showing typical facetted appearance of transgranular fractures.

Several specific comments must be made about these results. In the case of the Astroloy with serrated grain boundaries, Code $C$, no marked improvement in crack growth resistance was observed, compared to materials of comparable grain size. Since crack growth was transgranular this lack of any effect of the serrations is not surprising. In the case of the Waspaloy-2 samples with a duplex grain structure, the results are plotted in terms of the small sized grains. In both Waspaloy-2 and Waspaloy-3 samples there was no effect of longitudinal versus transverse sample orientations. The data for the remaining alloys in Table 2 do not 1 ine up with the Astroloy and Waspaloy data in Figure 3 . Generally the crack growth rates for the other alloys are significantly faster than would be predicted from Figure 3.

Other investigators have noted that coarse grained alloys can show lower crack growth rates in ambient temperature fatigue tests. Of particular interest is a recent 
study by Lindigkeit et al(12) of age hardened $\mathrm{Al}$ and $\mathrm{Ti}$ alloys. Coarse grained materials showed lower da/dN values, and the fracture surfaces displayed the flat, faceted appearance that was very similar to the fractures exemplified by Figure 2. Lindigkeit et al concluded that in alloys that display a high degree of planar slip a coarser grain size would minimize slip activity on secondary slip systems, thus allowing a greater degree of reversibility of deformation ahead of the crack tip under cyclic loading and hence a reduced rate of crack growth. A mechanism of this type is a plausible explanation for the present results since slip in superalloys at intermediate temperatures is generally planar and localized. The enhanced crack growth rates in air versus helium might also be related to slip reversibility; i.e., air might impair reversibility by oxidation damage in the crack tip region.

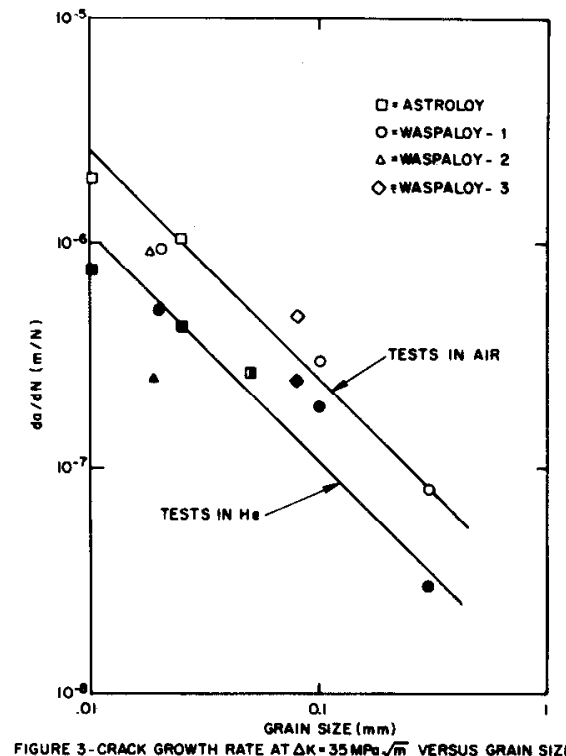

Other structural variables besides the grain size influenced the behavior. In the case of Alloy $\mathrm{x}-750$ the introduction of a coarse grain boundary $\mathrm{M}_{23} \mathrm{C}_{6}$ carbide plus $\gamma^{\prime}$ denuded zone by the intermediate heat treatment (Code $F$ ) caused the crack path to change to intergranular and produced a substantial increase in crack growth rate over the material aged only at $705^{\circ} \mathrm{C}$ (Code G). Intuitively one might expect the microstructure produced by the code $F$ 
heat treatment to be deleterious, but it must be noted that this deleterious effect was seen only when the samples were tested in air. When tested in helium the two heat treatments gave identical crack growth rates. Thus it would appear more correct to say that the code $F$ heat treatment made the alloy much more susceptible to the deleterious effects of the air environment.

Changes in the carbide morphology at the grain boundaries did not always affect the fatigue behavior. This lack of sensitivity to microstructure is illustrated by the results for NIMONIC alloy 115. In this case the two microstructures, Codes $\mathrm{D}$ and $\mathrm{E}$, gave identical crack rates in each environment.

The earlier tests on alloy 718 show that overaging is beneficial. Once again it should be noted that the environment may play a significant role. When tested in helium the alloy 718 results showed that the effects of heat treatment were reversed; i.e., the crack growth rate was slightly higher in the overaged condition(2). Thus here also it may be more accurate to say that the principal effect of the heat treatment was to change the sensitivity to the air environment.

These results with alloy $\mathrm{x}-750$ and alloy 718 indicate that microstructural effects observed in helium can be radically changed when the tests are conducted in air. However, the general effects of grain size were similar in both environments, with air producing about a 2.5 fold increase in crack growth rate at all grain sizes. Changing the environment evidently may produce either abrupt changes in behavior, or fairly continuous effects. It is noteworthy that the cases where abrupt changes occurred involved significant amounts of intergranular crack growth, while continuous changes in growth rate were observed under conditions of transgranular cracking. In general one might expect that environmental effects would be most pronounced, and perhaps most unpredictable, when the crack growth was intergranular.

Thus the optimum microstructure may depend upon the environment. Examination of fatigue crack growth of alloy 718 in a number of different environments showed that oxygen was the aggressive component in air(11). Sulfur containing environments were more aggressive than air and, in fact, under sulfidizing conditions, oxygen was found to help retard the effects of sulfur. Alloys that were developed by testing in air may perform well as long as oxygen is the dominant species influencing cracking. It is not at all 
certain however, whether microstructures optimized by testing in air would offer the best resistance to sulfurizing or other aggressive environments.

\section{CONCLUDING REMARKS}

The present results show that the fatigue crack growth rates can be influenced significantly by the microstructure. Coarser grain sizes markedly retarded the cracking rates. This effect of grain size seems best explained by the role of grain size in promoting slip on secondary systems in the region ahead of the crack tip.

As far as tests in air are concerned, overaging has often been found to be beneficial. Changing the slip behavior within the grains, or changes in the grain boundary microstructure have been suggested as the reasons for the improved resistance to crack growth. Just what specific heat treatments or specific microstructures are best is not generally known, and considerably more work needs to be done to detail the structure-property relationships.

If the microstructure is optimized to lower the fatigure crack growth rates, other properties may be adversely affected. Fatigue crack initiation probably will be enhanced by coarser grain sizes, and the creep strength generally will be lowered by coarser grain sizes and overaged microstructures. Microstructure must be optimized for the total spectrum of properties desired in service.

The environment is a significant variable at intermediate temperatures. Microstructures that are beneficial in one environment can be detrimental in another. Structures optimized by testing in air probably will remain effective as long as oxygen is the dominant aggressive element. When other species predominate there is no certainty that such microstructures will be effective.

\section{REFERENCES}

(1) H. F. Merrick and S. Floreen, Met. Trans. 9A, 1978, p. 1095.

(2) S. Floreen and R. H. Kane, Fatigue in Engineering Materials, in press.

(3) H. H. Smith and D. J. Michel, Naval Res. Lab., Memo Rep. 3810, Office of Naval Resarch, Arlington, VA, 1978. 
(4) W. J. Mills and L. A. James, ASME Paper No. 78 WA/PVP-3, ASME, NY 1978.

(5) M. Calvel and A. Pineau, Met. Trans. 9A, 1978, p. 471.

(6) M. O. Speidel, Proc. Symp. on High Temp. Matl's. in Gas Turbines, Elsevier Sci. Pub. Co., New York, 1974, p. 207.

(7) s. Floreen, AIME Symposium on Creep-Fatigue-Environment Interactions - in press.

(8) J. M. Larson and S. Floreen, Met. Trans. 8A, 1977, p. 51.

(9) D. M. Ward, results summarized in R. F. Decker, SteelStrengthening Mechanisms, Climax Moly. Co., CT, 1969. p. 137 .

(10) E. L. Raymond, Trans. AIME 239, 1967, p. 1415.

(11) S. Floreen and R. H. Kane, Met. Trans. 10A, 1979, p. 1745 .

(12) J. Lindigkeit, G. Terlinde, A. Gysler and G. Lutjering, Actas Met. 27, 1979, p. 1717. 